\title{
Cromossômios de Dysdercus
}

\section{(Hemiptera-Pyrrhocoridae)}

\author{
S. de Toledo Pisa Jor. \\ Prcfessor de Zoologia, Anatomia e Fisiologia : : \\ dș. Escola Superior de Agricultura "Luiz de Queiroz", \\ da Universidade de Săo Paulo
}

\section{INDICE}

Dysdercus Ruficollis (La) 210

Dysdercus Honestus Blbte 211

Dysdercus Mendesi Bibte 212

Discussão $\ldots \ldots \ldots \ldots \ldots \ldots$. 213

Summary $\ldots \ldots \ldots \ldots \ldots \ldots \cdot 215$ 
Apresento neste pequeno trabalho o resultado das primeiras otservaçoes dos cromossomias dos Hemipteros do genero Dysdercus (Pyrrhocoridae) realizadas com três espécies. Exemplares di: Dysdercus ruficollis (L), Dysdercus honestus Blöte e Dysdercus mendesi Blöte, gentilmente fornecidos em trascos de criaçåo pelo distinto especialista Dr. Luiz O. Teixeira Mendes, entomologista do Instituto Agronomico de Campinas, constiturram o material $\mathrm{cm}$ que se basearam os fatos aqui referidos.

Aperas os machos foram utilizados no presente estudo. Os testiculos foram. fixados em Allen-Bouin, modificaçăo de Bauer, incluidas em pirafina, cortados com 13 micra e coloridos pela ni:matoxitina ie Heidenhein.

Darei a seguir uma descriçăo abreviada daquilo que me parecel essencial relativamente a morfologia e ao comportaments dos cromossomios durante a espermatogenese das trés especles $\mathrm{em}$ questâ.

\section{DYSDERCUS RUFICOLIS (L.)}

Espermatogónios. Esta espécie possui espermatogónios com 13 cromossomios, isto e, 6 pares de autossomios e um sexo-cromossûnio. (Fig 1).

Espermatócitos. O cromossomio sexual, ante: de alcançar o estado de máxima contraçáo, pode apresentar-se mais ou menos alongado direito ou dobrado e, muitas vezes, tetradiforme, quer dizer, com uma incisæo longitudinal e uma constrição transvercal. As tétrades em formaçáo sáo alongadas. Va diacinese apresentam-se como duas maças bem separadas uma da outra po fílissimos conectivos, ás vezes invisivels. Tétrades em forma de cruz foram encontradas. O sexo-cromossomio possil nessa fare uma cinturinha mediana que chega a separar completsmerte as suas duas metades. 
No estado difuso do núcleo e nos estados precedentes po$\mathrm{d}=-$ se com facilidade reconhecer um plasmossomio e rảramente dois. essie organoide apresenta um diminuto granulo, que tanto pode se mostrar muito pálido, como intenssmente colorido. Neste ultimo crso o plasmossomio, propriamente, torna-sp indistinto e c corpusculo, que provàvelmente um organizador de nuclérlo, pode ser tomado por um pequenino cromossomio sexual.

Na metáfase o sexo-cromossomio fica no centro do circulo formado pelas tétrades autossomais. (Fig. 2). Nas vistas laterais exibe uma constriça mediana, pela qual ele se divide. $\mathrm{Na}$ metáfase secundiária fica fora do plano equatorial, algumas vezes muito proximo de um dos polos, incorporando-se, sem se dividir. no nikcleo que se constitul desse lado.

Corpos cromatóldes foram encontrados tanto nos espermatócitos primárias como nos secundários.

\section{DYSDERCUS HONESTUS BLOTE}

Espermatogónios. Possuem 15 cromossomios, ou sejam, 7 pares de autossomios e um sexo-cromossomio. (Fig. 3). Os cromossomias movim-se para os polos encurvados para eles.

Espermatócitos. Até a entrada do núcleo na fase dífusa nada de especial se assinala, a nzo ser a impossibllidade de se distinguir o plasmossomio. O sexo-cromossomio apräsenta-se sempre como um corpúsculo arredondado, bastante ç̣ndensado. Depo:s do estadn difuso pode-se observar a formáça das tétrades. Quando estas se tornam individualmente distintas pode-se constatar, nas malores, os dois cordoes laterals que ac constitucm e 3 abertura mediana tantas vezes referidá em outras fubjicaşбec. (Cf. PIZA 1945 e 1946, An. Esc. Sup. Arr. "Lulz de Queiros", Vs. 2 e 3). Tétrades alongadas, com diverşas abarturas como se os cordbes laterais se houvessem torcido frouxamente um sobre o outro. tétrades dobradas pela regla da abertura mediana, bem como tétrades anulares, foram observadas. Um pnucc antes da diacinese verifica-se que as tetrades, já bastante condensadas, apresentam, na reslao mediana, dols f1nos conertivos paralelos. As tétrades diacinéticas säo mals 
lo! igas do que Jargas e providas de uma incisăo longitudins:

dè uma constriçăo transversal bastante pronunciada.

Nia matáfase contam-se 7 tétrades autossomais dispostas eni círculo e um sexo-cromossomio na parte central (Fig. 4). thste é o menor elemento da placa. Divide-se na primeira divisãu e passa indiviso para um dos pólos na segunda.

Corpos cromatóides de dimensరes variadas foram encontrades.

\section{DYSDERCUS MENDESI BLOTE}

Espermatogónios. Sáo providos de 16 cromossomios de tam.ınhos diferentes, sendo 7 pares de autossomios e 2 sexo-crom. Jsscimios (Fig. 5).

Expermatócitos. Antes do periodo de crescimento observase ncs espermatócitos primários um enorme plasmossomio e dois pequenos cromossomios sexuais do mesmo tamanho, os qi:ais tanto podem apresentar-se separados, a distancias varisiveis, cumo muito próximas ou em contato mais ou menos estr sito. (Figs. 10 e 11). No periodo de crescimento o plasmossomio se reduz de tamanho e os sexo-cromossomios se apresentam sempre separados. Do estado difuso em diante torna-se dificil descobrir o plasmossomio (Fig. 12).

Durnntr a tormaçáo das tétrades nada se nota de esperial. $\mathrm{N}_{3}$ diacinese observam-se, bem espalhadas no interior do nucleo, 7 tatrades autossomais de tamanhos variados e 2 sexocrumussomios bastante pequenos, porém providos de nitida cinturinha mediana, o que lhes dá um aspecto tetradiforme. Conserva:n-se os cromossomios sexuais bem separados entre si até a metáfase. Nessa ocasiáo eles se aproximam, chegando a entrar om contato na parte central do circulo formado pelos aultossomios. (Fig. 6). Raramente se pode encontrar um dos sexocromussomios nc centrc e o outro na periferia, juntamente com os autossimmios. As vistas laterais da metafase revelam que as tétràdes autassnmaĺs sáo muito curtas e que os sexo-cromosso- 
mios, dispustos lado a lado, são alongados e providos de forte constrição mediana. (Fig. 7). Hles se dividem por essa constriçăo e portanto transversalmente, e as suas correspondentes metades caminham juntas para os polos.

Nas anáfases avançadas observa-se que os cromossomios sexuais, um bouco mais adiantadas que os outros, poem-se em estreito contato, de maneira que nas metáfases secundárias, a: invés de 9 cromossomios, como era de esperar-se, apenas se contan 8. (Figs. 8 e 9). Aqui também o par sexual fica no centro do grupo altossomal. (Fig. 9).

Na sigunda divisăo os sexo-cromossomios se separam, encaminhaıdo-se para pólos opostos. Todos os espermatocitos, por eonseguinte, recebem 7 autossomios e um cromossómio sexual.

No inicio da transformaçáo dos espermatídios em espermatozóides, pode-se verificar, com bastante clareza, que os autossốazios săo transversalmente divididas por funda constriçăo em dias partes perfeitamente distintas. (Fig. 13).

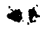

Gránulor cromatóldes săo encontrados no citoplasma dos espermatócitos.

Cromossómios somáticos. No cérebro de larvas encontrámos algumas anáfases cujos cromossomios se apresentavam fortemente recurvados para os polos. (Fig. 14).

\section{DIscussxo}

Em se tratando de três espécies bastante afins do mesiono gênero, era de se esperar o mesmo número e o mesmo comportamento dos cromossomios. Entretanto, nko fol isso o que se verificou. Dvsdercus ruficollis passui 13 cromossomios como número diplóide, D. honestus 15 e D. Mendesi 16. As duas primeiras espécles sáo, como as demais espécles conhecidas da familia, do tipo sexual $\mathbf{X}-0$, diferindo uma da outra por possuir honestus um par de autossomios a mais com relaçăo a ruficollis. Em amhas o sexo-cromossomio se divide na primetra divitio do espermatócito, passando indiviso para um dos polos na segunda. Na metáfase dos espermatocitas, tanto primários como 
secundários, encontra-se, por conseguinte, o mesmo número de crcmossomias, ou seja, 7 em ruficollis e 8 em honestus. Diferem ainda essas duas especies quanto ao plasmossónio, que na primnira é bem visível durante longo periodo da história dos espermatónitos, apresentando um "organizador", ds vezes táo intensamente colorido, que com facilidade poderia er toma do por um pequenino heterocromassomio, ainda mais que, quando nessr estado, o plasmossomio dificilmente pode ser reconhecido, dinda a sua extrema palldez, tendo-se a impressăo que o corpúsculo colorido se encontra livre na cavidade nuclear. Na segunda especle o plasmossomio náo se deira obser.. var.

$t$

Dysdercus mendesi é, sem duvida, a mais interessante das tres espenies Apresentando 7 pares de autassomios como $D$. honestus, possui, muito ao contrário, 2 sexo-cromossomios, a inves de 1. Nesse particular ela difere bastante das outras espécies da familia, aproximando-se do Lygaeidae Onocopelius fasciatus, estudado por WIISON. Os sexo-cromossomios, que såo do mesmo tamanho, na metáfase primária se dispóem lado a lado no centro do circulo formado pelas tétrades autassomais, podendo, al, entrarem em contato. Såo alongaitos e pro.. vidos de funda constriçăo transversal, através da qual se diviciem. As duas metades que se dirigem para o mesmo lado caminham juntas e uma vez atingido o polo entram em contato, de sorte que nas metáfases secundárias, ao invés de 9 cromorsomios, contam-se apenas 8. Na segunda divisso os sexo-cromossomios se separam, indo um para cada polo. $O$ mecanismo em questio pode ser considerado como sendo do tipo X-Y. Esta espécle é notável pelo tamanho do plasmossomio.

As espéries aqui estudadas confirmam pontos de vista estabelecidos em outros trabalhos, segundo os quais os cromossomios dos Femipteros sto normalmente providas de um cinetocore em cada extremidade. Assim, em Dysdercus honestus fi:ram encontradns anafases espermatogoniais com os cromossomios encurvadins para os polos, o mesmo tendo sido observado em tecidos somáticos de Dysdercus mendesi. Os sexo-cromossomios desta espécie orientam-se com 0 elxo longitudinal paralelaniente ao eixo do fuso e se dividem transversalmente pela constriçåo mediana. Tornam-se desse modo monocentricos e.issim permnnecem até o final da segunda divisăo. A regeneração da dicentricidade se opera no decurso da espermio- 
genese. De fato, em nenhuma das especies de Femipteros que pudemos ate agora estudar foi-nos passivel verificar, com tanta clareza como nesta, a duplicidade dos cromossomios das fases intciais da transformaçăo dos espermatidios em espermatozoides. Realmente, observa-se aqui que os cromossomios sãn bem divididos por forte constriçăo transversal.

\section{SUMMARY}

The chromcsomes of the males of three species of Pyrrhocoridae (Hemiptera) belonging to the genus Drsiercus were briefly described in this paper.

1) Dysdercus ruflcollis (L.) - Spermatogonia with 13 chromosonies, that is, with 6 pairs of autosomes and a single sex chromisome. Primary and secondary spermatocytes with $6+$ $X$ chromosomes, $X$ being equationally divided in the first division and passing undivided to one pole in the second. In the first metaphase $X$ occupies the center of the circle formed by the autosomal tetrads, in the second it lies outside the equatorial plaise, nearing sometimes one of the poles. All the chromosomes aivide transversely in the first division. A plasmosome provided with a granular organizer was observed. When intensely coloured, the organizer appears as if it were a tree corpuscle within the nucleus and in this case it may be missinterpreted.

2) Drsiercus honestus Blbte. - This specles has spermatogonia with 15 chromosomes, differing from the preceding one in having 7 pairs of autosomes instead of 6. At anaphase the spermatogonial chromosomes are bent toward the poles. Primary and secondary spermatocytes with $7+\mathbf{X}$ chromosomes. Plasmasome was not observed.

3) Dysiercus mendesi Blote. - Has the same number of autosomese as the preceding species (14), but 2 sex chromosomes instead of one. The spermatogonia are therefore provded with 16 chromosomes. Before the growth period of the spermatrcytes the sex chromasomes, which are small bodies of the same size, may appear separated or in contact with one another. At that time an enormous plasmosome is seen in the nucleus. Later in the history of the spermatocytes the ser 
chromosomes appear always separated. At diakinesis they skow a very deep median constriction. At metaphase they go to the center of the plate formed by the 7 autosomal tetrads, where they orient side by side with their length pasallelly io the spindle axis. Then they divide transversaly throughout the median constriction and their corresponding halves move together to the sume pole where they enter into intimate contact. Thus, instead of 9 , only 8 chromosomes are counted in the $\mathrm{si}_{i}$ condary metaphases. When the secondary spermatocytes divide, each resulting spermatid gets one of the sex chromosomes. In the beginning of the transformation of the sperma: into spermatoroa the chromosomes scattered within the nucleus are formed by two distinct parts separated by a very pronounced constriction as if they were metaphase chromosomes.

In this species somatic chromosomes have been observed in nerve tissue of the larva. As it was stated, anaphase chromosomes move toward the poles pronouncedly bent to them.

The facts presented here, are in full agreement with the assumption made by the present writer in other papers, that Hemiptera chromosomes are provided with a kinetochore at each end. (Cf. PIZA 1945 and 1946, An. Esc. Sup. Agri. "Luiz de Queiroz", V. 2 and 3). The shape of the chromosomes of the spermatids of Dysilercus mendesi seems to indicate that the restahlishment of the dicentricity takes place at this stage. 

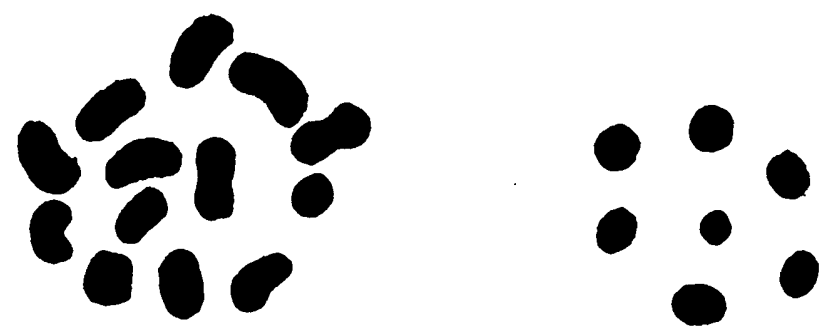

Figs. 1 e $2-$ Dysdercus ruficollis: 1) Metáfase \&spermatogonial; 2) Metáase primária.

$(x 6500$ e 5200)
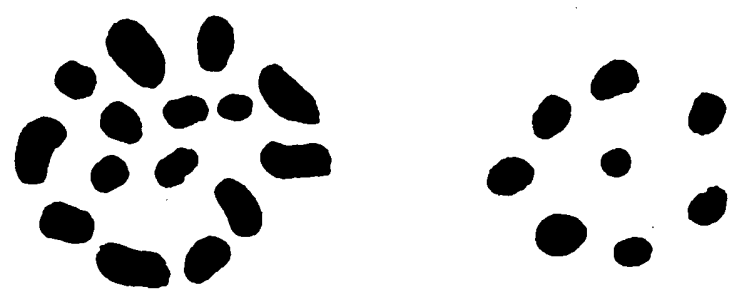

F g. 3 e $4-D y s d e r c u s ~ h o n e s t u s:$ 3) Metáfase espermatogonial; 4) Metáfase primária.

$(x 6200$ e 5200$)$
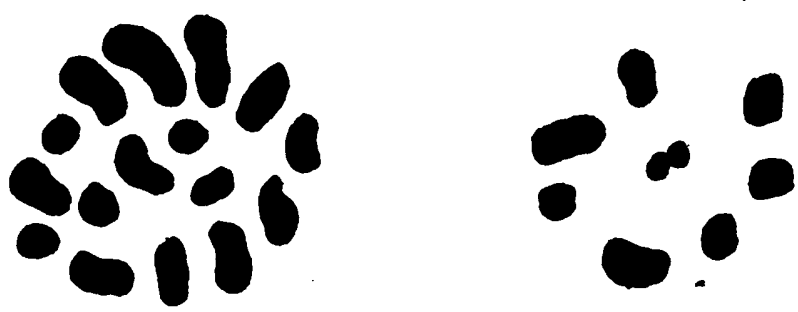

Figs. 5 e 6 - Dysdercus mendesi : 5) Metáfase espermatogonial; 6) Metáfase primária $(x 5600$ e 4200$)$ 

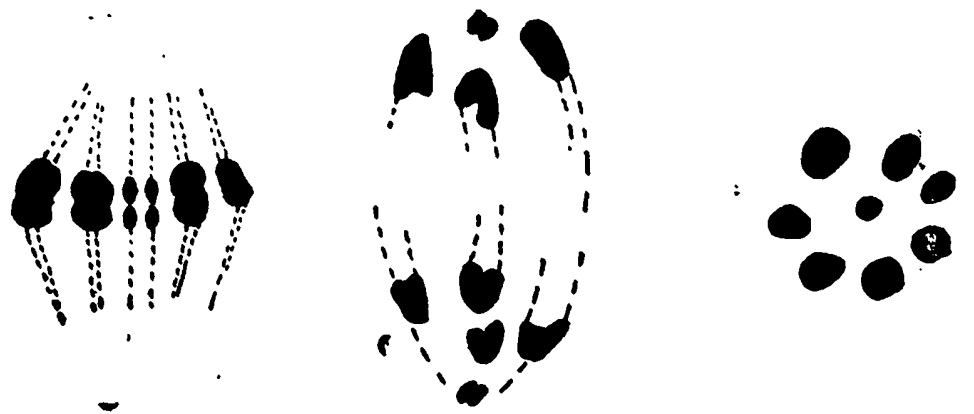

Figs. $7, \overrightarrow{8}$ e $9-$ Lysdercus mendesi : 7) Vista lateral da metáfase primária mostrando os sexo-cromossómios na parte central; 8) Anáfase primária mostrancio os sexo-cromossomios unidos nos pólos; 9) Metáfase secundária. $(x 4200,4200$ e 5000$)$.
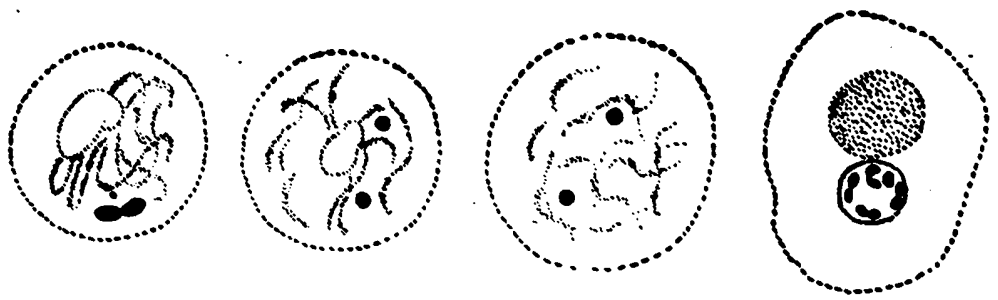

Figs 10 1!, 12 e 13 - Dysdercus mendesi : 10 e 11) Núcleo do espermatócito prirsário antes do estado difuso mostrando os sexo-cromossómios respectivamente unidos e separados $(\times 2700)$; 12) Núcleo primário no estado difuso mosirando os sexo-cromossómios separados $(x 2400)$; 13) Espermatíclio jovem em cujo núclec se encontram autossómios formados î.je ci.las partes sepnradas por funda constriçăo transversal. (x2300).

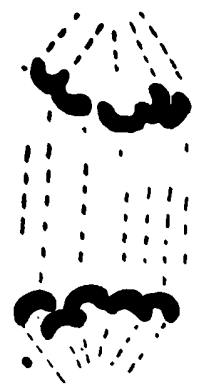

Fig. 14 - Dysdercus menifesi: Anáfase em célula nervosa da larva mostrando os cromossomios fortemente recurvados para os pólos. 